\title{
Jacek Makuch
}

Dr inż.

Politechnika Wrocławska, Wydział Budownictwa Lądowego i Wodnego;

Katedra Mostów i Kolei

jacek.makuch@pwr.edu.pl

DOI: $10.35117 / A \_E N G \_18 \_10 \_03$

\section{Problems on the edge of tram track subgrade and road street construction}

\begin{abstract}
In article the problem of independent tram track subgrade and road street design and construction in case of tram tracks integrated with streets pavement and track-road level crossings was concerned. Terminological dissimilarity applied in road and railway branches was pointed out. Types of problems performed on the edge of this branches were defined. Review and analysis of tram track subgrade constructional solutions used in Wrocław during last 25 years were made. Manners of solution defined problems were proposed. In summary importance of analyzed problems were highlighted and the necessity of obligatory rules revision was demonstrated.
\end{abstract}

Keywords: Tram track; Subgrade

\section{Introduction}

Trams run in most cases parallel to the roadway. The tracks are placed in the middle or on the side of the cross-section of the street. A more convenient solution from the point of view of traffic conditions is to run tram lines on dedicated tracks. They can then be separated from the roadways adjacent to them by green belts. In this case, the construction of tram track and roadway substructures does not touch each other - they can be designed, and with a relatively large green belt width, they can also be built independently of each other.

The situation is completely different when the track is directly adjacent to the road and is located between the two spaces:

- high curb - separating the road from the track not accessible for traffic of other vehicles,

- lowered curb - separating the road from the built-up track available for traffic of other vehicles (emergency services, city buses, taxis, electric cars),

- lack of any structural element, i.e. a smooth transition of the surface of the roadway into the surface of the built-up track.

The last of these solutions may occur in the following two cases:

- lanes of vehicular traffic carried out together with tramway traffic - so-called "nonseparated" tracks,

- transverse (perpendicular or oblique) traffic for vehicular traffic through the track.

In these cases, the subgrades of tramway tracks and roadways are in contact with each other - it is not possible to design them completely and build them.

\section{Terminological differentiation}

In this chapter, road solutions will be compared with railways, not streetcars - because the latter is much worse "legally enforced". Referring to the analysis of the term "trestle" records regarding this element appear in the "railway" regulations [9] [8], moreover, PKP has its own manual [1] dedicated exclusively to the subgroup issues. In the case of tramway infrastructure, the situation is radically different. The "tram" [11] and tramway "take-off" rules [6] only contain short entries regarding embankments, crossings, drainage, and filtration 
layers. Very rarely the term "track bed" is used as an autonomous term, there is no explicit definition. It is true that the author of the article at the previous subgrade conference proposed his own definition of the term "tram track subgrade" [3], unfortunately officially - nothing like that.

In railway engineering, a very clear division of track structure elements applies:

- surface (chapter 4 of Regulation [9]) - i.e.: rails, fastenings, sleepers and ballast,

- subgrade (chapter 3 of the regulation [1] and the entire manual [1]) - i.e. all elements under the ballast: protective layers (covers), embankments or trenches, buttresses, drainage and safety devices and the ground.

The situation is somewhat more complicated if the track does not have a classic but unconventional (non-bedded) structure - then the "beginning" of the substructure is usually taken from the bottom of the concrete slab, replacing the foundations and ballast in this type of surface.

In road wheel engineering [2], the surface is:

- upper layers: abrasive, binding, main and lower foundation,

- lower layers: auxiliary foundation and frost-proof layer.

- under the surface there is a "ground surface of the surface", which consists of:

- layer of the improved substrate,

- indigenous soil - in the case of a cut or a packed soil - in the case of a embankment.

The "track bed" therefore corresponds to the road "ground surface", and more specifically: the railway "protective layers" (cover the road) layers of the improved ground ", but also the" frost-proof layer "of the surface (!), And the railway" ground " - road "home soil".Only in the case of soil layers from which the embankments are built - on the roads and in the railways we have the consistency of the terminology. In addition, there are large discrepancies in the naming used. Also, the boundary between the surface and what is below it is somewhat different in the case of both industries.

\section{The problem of the industry's contact}

In projects, road and rail (tramway) industries are developed together or separately depending on:

- the design stage - for KPP most often together, while for PB or PW it is usually already separately,

- local conditions - as ordered by the ordering party (in OPZ).

Of course, a higher probability of problems at the interface between the two industries occurs in the case of separate studies.

The main (most frequent) type of problem is the incompatibility of the presented solutions. The track trader, in his structural cross-sections, draws in detail track solutions, while the structure of the roadway adjacent to the track presents in a simplified way, most often providing a commentary "according to a road development". The road industry is doing the same - creating a part of the project. Unfortunately, it often happens that the initially agreed construction solutions are subject to various modifications during the reconciliation of projects, which the engineers forget to inform each other and in the final track design, the track structure is correctly presented, and the roadway next to it is no longer necessary, and in the project on the road - vice versa.

The problems described above, although troublesome - because they are misleading, fortunately, are still "straighten". Worse, if both construction solutions: road and rail - they just do not match. In most cases of investment processes, there are plans to rebuild streets treated as a whole. Most often, road construction offices tend to enter tenders, which are later selected for cooperation by other industry players: reconstruction of networks (power, 
sewage, water, gas, teletechnical and other) and track industry - if a tram line is planned to be reconstructed down the street. In this case, its "order" must be determined at the beginning of the design. Most often the leading industry is, in this case, a "road worker". It is he who prepares the first version of the solution in the plan, profiles, and constructional crosssections, and the "torrent" and "installers" somehow "adapt" to it, obviously reporting the necessity of corrections - in the places of demanding ones. Unfortunately, it happens that cooperation does not work as it should.

The author of the article began his professional career (more than 20 years ago) in a large state office of projects, in which different engineers worked in subsequent rooms of the same building. A jargon of "getting along" a certain detail of the project required taking drawings with you and walking to an adjacent room. Today, despite the possibility of using the benefits of modernity such as mobile phones or e-mail, such "agreement" in the opinion of the author of the article seems to be more difficult and less precise.

At the end of this chapter it should be mentioned that in theory the problem of cooperation between a "road person" and a "tram track" should not take place at all, because in the light of the regulations in force in Poland, to perform independent technical functions of a designer or construction works manager in the field of tramway tracks - persons with construction qualifications in road specialty are authorized. Theoretically, therefore, a road designer should have the ability to design tram tracks. Practice shows, however, that this is rare and most often road designers use designers in such situations but beware! not by tram only railway, because there is no separate category of permissions in the applicable regulations - only for tram tracks.

\section{The difference in the applied density measures}

It is quite an embarrassing practice to use various measures of ground density and built-in layers in projects and on construction sites.

In road construction, they are most often used:

- density indicator $\mathrm{I}_{\mathrm{S}}$ - according to the norm withdrawn in 2015 [5],

- according to the norm withdrawn in 2015 [7],

- Californian CBR load index - according to the standard as above,

- load capacity groups Gi (and from 1 to 4) - according to Annex 4 of the "road" regulation [10].

In railway construction, the compaction and secondary modulus of deformation are also currently used, only that defined according to the attachments of the railway sub-rail instruction [1] (third and second respectively).In tram construction, in the "old" guidelines from 1983 [11] a minimum value of the soil compaction index (soil at the bottom of the bed) is given, determined according to the normal method, but still the previous version of the standard [2] - equal to 0.95 maximum density. This information is repeated in a somewhat new tram acceptance standard [1] from 1998, this time with a reference to the current version of the standard of that time [2].

It is true that in the professional literature there are given the formulas, tables or nomograms that allow you to convert one measure of density to another, but the creators of these methods indicate their approximate character.

The annexes of the railway sub-terminal instruction mentioned above [1] cite geotechnical and road standards [5], [7], but there are subtle differences between them.

The definitions of some of the measures considered have also changed over the years or have been transferred to other documents. Since 1998, a 3/4 multiplier has been introduced into the formula for the deformation module. In the new single text of the Road Regulation published in January 2016, we will no longer find Annex 4 - defining loadbearing groups of 
the $\mathrm{G}_{\mathrm{i}}$ surface and referring to the CBR load index, this information was transferred to a previously published catalog of typical flexible and semi-rigid pavement constructions [2].

\section{Analysis of solutions used in Wroclaw}

The author of the article has reviewed structural solutions used in the case of new or modernized tramway tracks in Wrocław over the last 25 years. Compared to a similar survey carried out 2 years earlier [3], this time it was limited only to cases of built-up tram tracks adjacent to roadways.

The following two periods can be distinguished in the history of the development of tramway construction solutions built into roadways:

- Initially, tracks were used according to the classic solution (rails on transverse sleepers and ballast) called "conventional" or "ballast", which were built with paving stones (later also with reinforced concrete slabs) or layers of asphalt concrete or cement - the main disadvantage of this solution were differences in rail deflection in relation to the neighboring road building, which contributed to the rapid degradation of the pavement so constructed,

- in the later period a number of new solutions called "unconventional" or "discharges" were developed, in which in the support and fastening of the rail there was a departure from the classic rail grid (rails on transverse sleepers) and the use of solutions taken from other areas of construction (e.g. foundations under machines, fixing of crane rails) or completely new, previously unused ideas, while in the field of building, foundation and drainage there was a similarity to solutions used in road engineering.

In Wrocław, built-up ballasting tracks are already present in only a few places. Their last "modern" realization is the section between the Reagan Roundabout and the Szczytnicki Bridge (the year 2001). The vast majority of built-up tracks have stand-alone structures more similar to the system of applied layers for solutions used in road engineering.

The constructions of these tracks, of course, differ from the roadway construction, because, as it were, by definition, in road transport, a rubber-coated wheel touches the road surface with a much larger surface than a steel wheel with steel rail in rail transport. As a result, to obtain a comparable value of the pressure distributed over the surface, track structures "need" a higher altitude than road ones.

The too large variation in their height may result in different stiffness of the built-up road surface in relation to the adjacent roadway, and hence - the occurrence of different deflections of the surface under load from the wheel of the same road vehicle passing between the road and the track. This may be the reason for the effect of "threshold" (Fig. 1) - similar to that occurring in road rigid surfaces when two adjacent concrete slabs set on a susceptible foundation, will not stay in the dilatation (necessary due to the contraction occurring in cement concrete ) connected with dowels. 


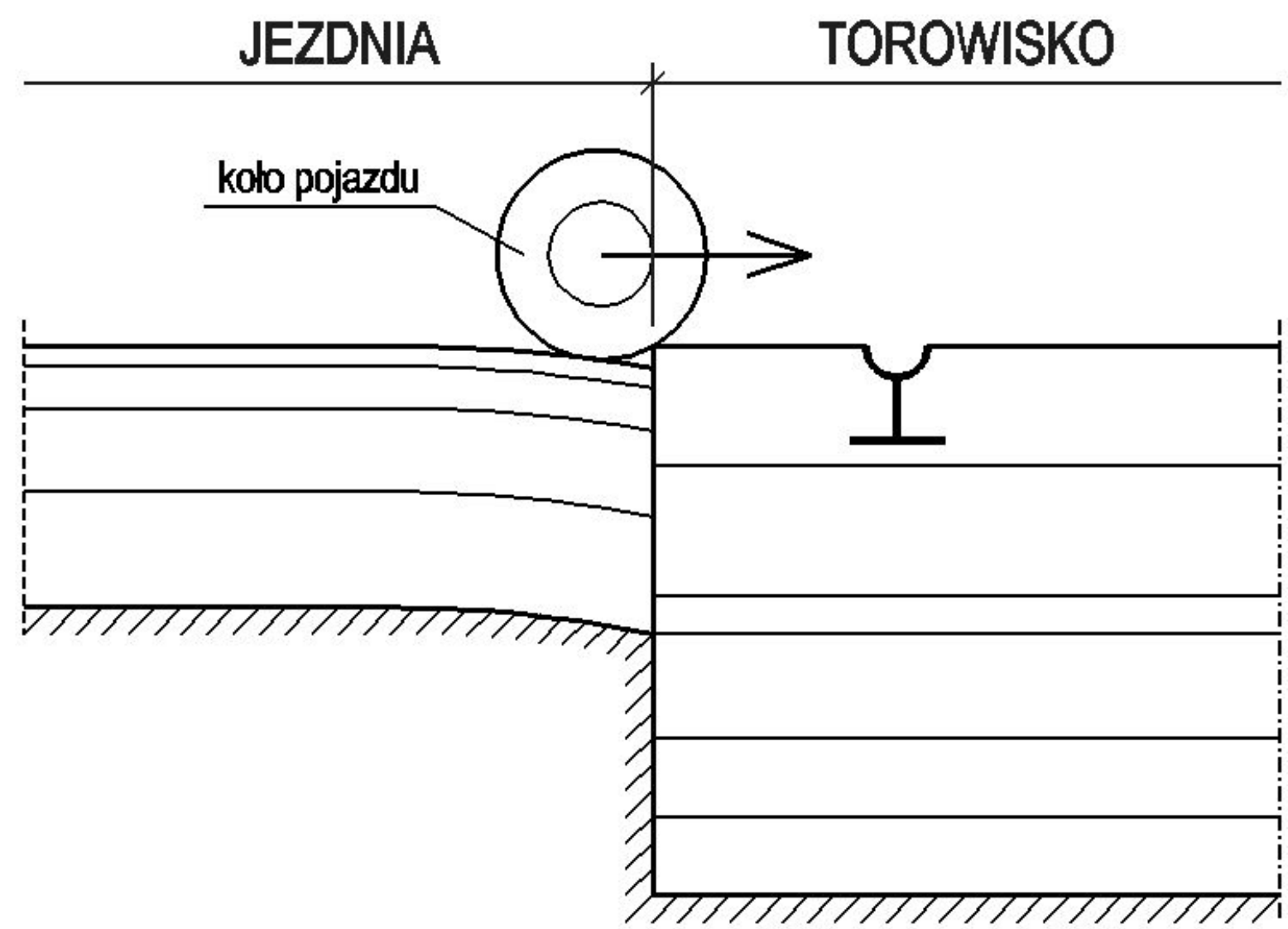

1. The "threshold" effect with too big differences in road stiffness and adjacent track

It should be noted, however, that in the considerations it is not so much the "threshold" is a problem here - firstly, the difference in height to be overcome by a road vehicle is small, and secondly, if a tracked road separates from the road with a lowered curb, the wheel must still be overcome some difference in height. The problem, in this case, is the loss of continuity of the surface (crack, gap) appearing in the place of the occurrence of this "threshold", because it can become the germ of the degradation process of the entire road cross-section structure with a built-in tram track. Admittedly, this does not apply to solutions in which a gap (dilatation) was designed by definition and provided for filling with a material of adequate flexibility and tightness. However, as practice shows, solutions for this type of designers reach relatively rarely.

The analysis of the solutions applied in Wrocław, from the point of view of the diversity of the stiffness of the tracks in relation to the adjacent roadways, allowed to identify the following three types of solutions (Figure 2), which in the author's opinion should be considered unfavorable:

- too big difference in the height of the roadway structure and track (a),

- curb (on the bench with resistance) between the road and the track - with much weaker "support" in relation to the roadway and track (b),

- as above, but additionally with a narrow strip of the surface of the built-up track (c). 
(a)

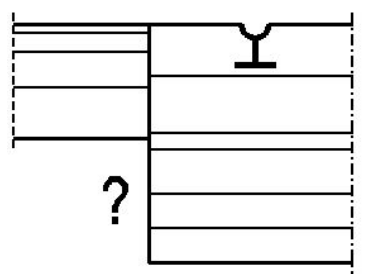

(b)

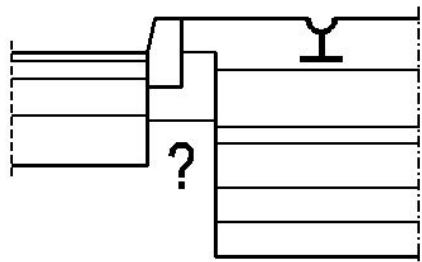

(c)

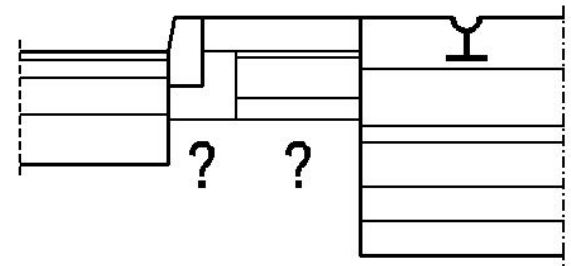

2. Unfavorable solutions (description in the text)

As a form of counteracting the "threshold" effect, the following three types of solutions are possible (Fig):

- dowelling of contacting layers that are in contact with each other,

- the stepping of the lower layers of the track structure,

- variable thickness of the lower layers of the roadway construction on the principle of a transition zone.

dyblowanie

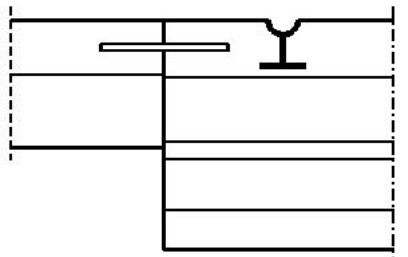

schodkowanie

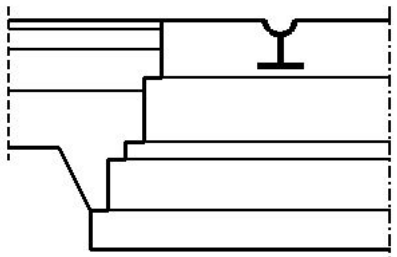

strefa przejściowa

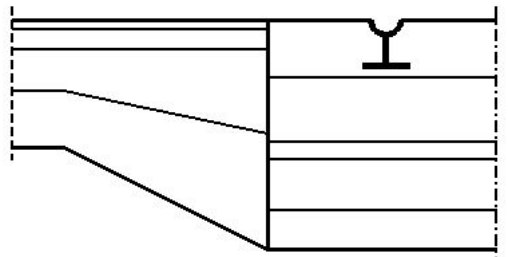

3. Proposals to counteract the occurrence of the "threshold" effect (description in the text)

The solution consisting in doweling of the contact layers that are in contact with each other is only possible if the layers are of cement concrete - which is quite rare in urban roadways and built-up rails. In turn, the solution consisting of stepping the lower layers of the track structure may raise concerns about transferring cracks reflected on the surface layers from the places of the "ends" of the stairs.

According to the author of the article, the last of the presented proposals seems to be the most advantageous - referring to the idea of transitional sections used along the railway track sub-tracks [1] in places where their stiffness changes (at engineering facilities, when changing the structure of bedding track to non-bedding tracks).

\section{Summary}

In the author's opinion, the analyzed issues are of great importance because a badly designed contact of the tramway foundation and road surface becomes the most common reason for initiating the cracking of the surface, which turns out later to be the beginning of the degradation process of the entire roadway cross-section with a built-in tram track in the form of a sequence consecutive events: water infiltration, freezing and thawing, propagation of cracks, loss of continuity of the material, contamination, corrosion, cracks, losses and cracks, collapse.

Even 30 years ago it seemed that the problems raised in this article, thanks to the successive separation of tram tracks from the roadways of the general movement, with time will be less and less "give in" to the designers and the builder until they completely disappear. However, history has changed a bit differently - we are currently observing a return to 
solutions involving the incorporation of tram tracks into road construction. There are at least several reasons for this:

- building tram tracks to allow the passage of emergency vehicles (so-called "life belts") and buses (so-called "PATs") so that they can avoid traffic jams,

- introduction of tram routes to traffic zones and even residence,

- aesthetics of streets' appearance - resistance of city architects and conservators against the use of ballasting tracks in the areas of old-town buildings,

- counteracting acts of vandalism - by covering the gravel,

- facilitating the process of keeping the tracks clean in cities - thanks to smooth, even surfaces,

- mute tracks - built-up rail rails do not emit additional noise.

Over the last 25 years, we have also observed an increase in the variety of solutions used in the construction of tramway substructures, the reasons for this process are described in detail in [3]. This has its impact in the form of a number of new ways of solving the contact between streetcar tramway substructures and roadway construction appearing in projects different to each other. Unfortunately, the review of the solutions carried out by the author of the article shows that not all of them should be considered beneficial.

In developing and disseminating new correct solutions, the basic obstacle is old, outdated and inconsistent regulations and normative documents. The need for a new version of the guidelines for the design, construction, and maintenance of tram tracks, which has been raised for many years, should take sub-rail issues to a much greater extent than is contained in their current form [11].

The author of the article would also like to submit a postulate to regulate the issue of rights in the field of designing and construction of tram tracks - by allowing also the designers with railway authorizations to this scope. Maybe this will end the very unjust, according to the author of the article, the practice that the designer with railway rights, if he is the right author of the tram track project, cannot name his work with the name and permissions and only acts as a designer's assistant, whereas a designer with road rights does so which really proverbs "stamps" and makes a signature.

\section{Source materials}

[1] Id-3 (D-4) Warunki techniczne utrzymania podtorza kolejowego, PKP PLK Warszawa 2009

[2] Katalog typowych konstrukcji nawierzchni podatnych i półsztywnych, Załącznik do zarządzenia Nr 31 Generalnego Dyrektora Dróg Krajowych i Autostrad z dnia 16.06.2014

[3] Makuch J.: Podtorza wrocławskich torów tramwajowych, VIII Konferencja NaukowoTechniczna: Problemy budowy i naprawy podtorza kolejowego, Jelenia Góra 1314.10.2016 oraz Przegląd Komunikacyjny nr 112016

[4] Obwieszczenie Ministra Infrastruktury i Budownictwa w sprawie ogłoszenia jednolitego tekstu rozporządzenia Ministra Transportu i Gospodarki Morskiej w sprawie warunków technicznych, jakim powinny odpowiadać drogi publiczne i ich usytuowanie, DzU RP z 29.01.2016, poz. 124

[5] PN-B-04481:1988 Grunty budowlane. Badania próbek gruntu.

[6] PN-K-92011: 1998 Torowiska tramwajowe. Wymagania i badania.

[7] PN-S-02205:1998 Drogi samochodowe. Roboty ziemne. Wymagania i badania

[8] Rozporządzenie Ministra Infrastruktury i Rozwoju zmieniające rozporządzenie w sprawie warunków technicznych, jakim powinny odpowiadać budowle kolejowe i ich usytuowanie, DzU RP z 30.06.2014, pozycja 867 
[9] Rozporządzenie Ministra Transportu i Gospodarki Morskiej w sprawie warunków technicznych, jakim powinny odpowiadać budowle kolejowe i ich usytuowanie, DzU RP Nr 151 z 15.12.1998, pozycja 987

[10] Rozporządzenie Ministra Transportu i Gospodarki Morskiej w sprawie warunków technicznych, jakim powinny odpowiadać drogi publiczne i ich usytuowanie, DzU RP $\mathrm{Nr} 43$ z 14.05.1999, pozycja 430

[11] Wytyczne techniczne projektowania, budowy i utrzymania torów tramwajowych, MAGTiOŚ 1983 